\title{
Smallholder Commercialization and Commercial Farming in Coffee-Spice Based Farming System of South West Ethiopia
}

\author{
Abdu Mohammed ${ }^{\mathrm{a}}$, Melkamu Baze ${ }^{\mathrm{a}}$, Mohammed Ahmed \\ ${ }^{a}$ Tepi Agricultural Research Center, Ethiopian Institute of Agricultural Research Ethiopia. \\ abdulahi.moh@gmail.com,melkamubazie@gmail.com,moxe86@gmail.com
}

\begin{abstract}
This study assessed the determinants of smallholder commercialization and the status of commercial farms in terms crop type, cropping system and technology use in Sheka, Kaffa and Bench Maji zones using descriptive statistics and linear regression model. The result showed that the average smallholder commercialization in the study area was $60 \%$, which is by far above the national average, 35\%. The average marketability index of coffee, ginger, turmeric, maize and sorghum are found to be $80 \%, 83 \%$, 85\%, 51\% and $35 \%$, respectively. The result also indicate that the extent of smallholder commercialization is positively influenced by household education and farming experience, total harvest and the marketed proportion of high value crops, whereas negatively determined by family size, land holding, distance to village market, source of fertilizer and improved seed. Regarding commercial farms, more than 94\%, 92\% and 50\% of commercial farms in Sheka, Kaffa and Bench Maji zones respectively, engaged in growing of high value crops. Given that these crops are one of the major crops being grown by smallholder farmers, strengthening the linkage between smallholder farmers and commercial farms could enhance the commercial transformation of agriculture in the study area. Besides, that about $90 \%$ and $93 \%$ of commercial farms in Sheka and Kaffa zones respectively follow sole cropping system, whereas $60 \%$ of commercial farms practiced the same system in Bench Maji zone. Moreover, commercial farms in the study area operate farming activity below expected level in terms of modern input use. Except maize, rice, ginger, turmeric, coffee and tea farms, the majority of commercial farms did not use improved crop technologies.
\end{abstract}

Keywords: Commercial farms, Commercialization, High value crops.

\section{INTRODUCTION}

Agriculture sector plays crucial role in Ethiopia's economy. This sector provides $96 \%$ of the entire agricultural output, support livelihood for $85 \%$ of the population, contribute about $43 \%$ of gross domestic product (GDP), generate more than $90 \%$ of export value and supply over $70 \%$ of industrial raw materials for domestic industries (NBE, 2014; MoA, 2011). The agriculture sector is dominated by smallholder farming which makes over $96 \%$ of the entire agricultural land. Given these facts on the ground, Ethiopia has been implementing a number of policies and strategies to bring structural transformation in the productivity of the smallholder agriculture and to move towards market oriented business. Accordingly, the whole growth and development strategy which the country has implemented so far in the agricultural sector gives a strong emphasis to the intensification and commercialization of smallholder agriculture as a means to achieve poverty reduction and food security.

Commercializing smallholder farmers is part of an agricultural transformation process in which individual farms shift from a highly subsistence-oriented production towards more specialized production targeting markets both for their input procurement and output supply (Jaleta et al, 2009). Like many African countries, Ethiopia's potential with respect to commercial agriculture is largely untapped, since the transition from subsistence to commercial agriculture usually takes a long process to transform to a fully commercialized agriculture (Pingali and Rosegrant 1995). However Baumgartner et al, (2013) indicated that the transformation process of smallholder farmers could be speed up if the driving force of commercialization function in a synchronized order and smallholder farmers should be linked with domestic and international agricultural market.

Also, it is believed that for agriculture to continue serving as an engine of growth in the coming years, it has to progress in terms of commercialization with more intensive farming, increasing proportion 
of marketable surplus and providing raw materials for industries. In this regard, large scale commercial farms with better capital, access to market information and with modern agricultural knowledge is indispensable and might have positive spillover effect on the transformation of smallholder agriculture through dissemination of improved technologies and new agricultural practices (Kuma, 2003). Besides, large scale commercial farms could serve to link smallholder farmers with domestic and international agricultural markets to guarantee and speed up all rounded agricultural transformation process. As a result, the current Government policies on agricultural sector favored wider and active participation of both local and foreign private investors and supported the establishment of large scale farms. However, the contribution of commercial farms to smallholder commercialization, either through sharing of technologies, skills or out sourcing scheme, could be realized within a reliable short period of time if the type of crops grown by commercial farms matches with what is actually being cultivated by smallholder farmers'.

Despite all the policy decision and efforts to transform the agricultural sector, the current status of agricultural commercialization in the country is a source of major concern as the commercialization process is hardly organized and characterized by low progress (Bonaglia et al, 2007). Agro-ecology and niche-specific information and recommendations about the extent of household and crop specific commercialization are rare (Gebreselassie and Sharp, 2008). Besides, information on the status of commercial farms in terms of crop type, cropping system and input use is very limited. Understanding area specific determinants of household commercialization is essential to design and implement appropriate policy and strategies to encourage farmers to actively get involved in market oriented agricultural activities in which they have comparative advantage. Moreover, quantitative information on commercial farms about the type of crops grown, cropping system and technology use are crucial for planning and promoting the establishment of commercial farms, and to design and formulate policy direction as how to link and facilitate the transformation of smallholder farmers to commercial farms in the long run. Thus, this study assess the determinants of smallholder commercialization and status of commercial farms in terms crop type, cropping system and technology use in coffee-spices based farming system of Sheka, Kaffa and Bench Maji zones

\section{Methodology}

\subsection{Description of the Study Area}

This study was carried out in SNNPR, Keffa, Sheka and Bench Maji zones, where coffee-spice based farming system is dominant. These zones are known for their dense forest resources and high potential of coffee and spice production. The majority of smallholder farmers in the study zones mainly depend on coffee, cereals, spices and livestock production. Coffee and lowland spices compose the major share of cash income while maize, sorghum and false banana are mainly produced for home consumption. Moreover, the study sits is one of the potential area in SNNPR in receiving considerable number of large scale commercial farms and allocating large amount of land to commercial agriculture (James et al, 2014). The estimated total area of Kaffa, Sheka and Bench Maji zones is about $32,702.73 \mathrm{~km}^{2}$, which is about $30.9 \%$ of the total area of the region. The three zones have a well-distributed sufficient rainfall, with only a short period of a dry spell, as well as a warm to hot temperature. The annual mean temperature of the zones ranges between 10.1 to $27.5^{\circ} \mathrm{C}$, whereas the average annual rainfall varies between 400 to $2200 \mathrm{~mm}$ (SNNPRS website). The total population of the three zones is estimated to be 2,115,006, of which 1,044,220 is male and 1,070,786 are female; 333,498 or $15.8 \%$ of its population are urban dwellers, whereas $1,781,503$ or $84.2 \%$ are living in rural areas (CSA, 2013).

\subsection{Type of Data and Sampling Procedures}

The data used for this study was derived from three sources: The first source was the community level group discussion, during which community-level qualitative data was collected. The second source was questionnaire based formal survey, from which household and farm level data were collected. The third source was secondary data from CSA to have full picture about the type and distribution of commercial farms in the study area. For smallholder agriculture, the household survey was conducted during the period of December 2012 to August 20113. Only one woreda, Yeki, was purposely selected from Sheka zone for household survey. Multi-stage sampling procedure was used to select the final sample units. In the first stage, all villages of the district were clustered in to three cluster groups based on their coffee-spices production potential. In the second stage a total of three villages, 
one from each cluster, were randomly selected. Finally, 153 households were selected from the three villages based on proportionate and random sampling method.

For large scale commercial farms, CSA (2013) data was used to have full picture about the type and distribution of large scale commercial farms in the three zones (Kaffa, Sheka and Bench Maji). In addition, formal survey was employed to support CSA data with detailed farm level production data. Due to time limitation and logistic problem, commercial farms covered by formal survey were selected only from Sheka and Bench Maji Zones. As a result, 18 large scale commercial farms were selected out of 64 farms from the two zones using random sampling technique. In this study any farm plots, that can be owned and operated either by government, private companies or non-governmental institutions, with a size larger than 9 hectare was considered as large scale commercial farm.

\subsection{Data Analysis}

Descriptive statistics, Household Commercialization Index (HCI) and linear regression model were used for the analysis of this study. Descriptive statistics was used to describe and analyze the socioeconomic characteristics of small holder farmers and type and distribution of large scale commercial farms. The HCI was used to determine both household and crop specific level of commercialization. Mathematically it is expressed as:

$$
\mathrm{HCI}=\frac{\text { Total Volume of Crop } \text { Sold }}{\text { Total Volume of Crop } \mathrm{Pr} \text { oduced }} \times 100
$$

The index measures the extent to which household crop production is oriented towards the market. A value of zero would imply a totally subsistence oriented household; the closer the index is to 1, the higher the degree of commercialization (Paul J et al, 1999; Govereh et al, 1999). For the determinants of household commercialization, most previous studies used ordinary least squares (OLS) model since the dependent variable is continuous. Existing literature on agricultural commercialization (Ogbonnaya Ukeh OTEH, 2014; Rahut, D.B., et al, 2010) recommended three possible model specifications, Linear-linear, Log-log and Log-linear or Semi-log, while using OLS to model agricultural commercialization. The choice between linear versus log specification should be made primarily on the basis of the underlying economic logic. But there are two major reasons that decision on the choice of model specification should not always be made depending on the underlying economic theory. First, the real world data is not usually so clean to fully explain the underlining economic assumption, and secondly sometimes there is no guiding economic theory to make decision. Because of these, it is also advisable and very helpful to have more quantitative methods to choose among specifications. As a rule of thumb $\mathrm{R}^{2}$ is often used by many researchers to choose the best functional form. However, as indicated by Pesaran, M. H, (1974) using $\mathrm{R}^{2}$ could be an appropriate statistical technique provided that we are comparing two models with the same left hand side (LHS) variable, i.e linear-linear with linear-log, or log-linear with log-log. In this study we used maximum likelihood estimation (MLE) approach to compare and choose the linear versus log specification model. The Box-Cox test provides a MLE comparison of log vs linear specifications. The Box-Cox transformation takes and transforms the dependent variable using the following formula;

$$
L_{i}=\left(Y_{i}^{\theta}-1\right) / \theta
$$

Where $L_{i}$ is the transformed dependent variable, $Y_{i}$ is the original dependant variable and could be some value between $-1 \& 1$. Finally, the method reports the value of $\theta$ that maximizes the MLE score. According to COX, D. R. (1962)

If $\theta=1$, linear specification is appropriate.

If $\theta=0, \log$ specification is appropriate \&

If $\theta=-1$, an inverse $\left(1 / Y_{i}\right)$ specification is best. 
Therefore, in this study, based on the calculated $\theta$, linear regression model was chosen as the lead equation. The implicit form of the model is stated as:

$$
Y_{i}=\beta_{0}+\beta_{1} X_{1}+\beta_{2} X_{2}+\beta_{3} X_{3}+\ldots \ldots \ldots \beta_{n} X_{n}+\varepsilon
$$

Where $\mathrm{Y}_{\mathrm{i}}=\mathrm{HCI}(\%), \mathrm{X}_{1}=$ household sex, $\mathrm{X}_{2}=$ marital status, $\mathrm{X}_{3}=$ educational status, $\mathrm{X}_{4}=$ farming experience (years), $\mathrm{X}_{5}=$ family size, $\mathrm{X}_{6}=$ land holding (ha), $\mathrm{X}_{7}=$ total harvest, $\mathrm{X}_{8}=$ marketability index of high value crops, $X_{9}=$ stock at harvest, $X_{10}=$ distance to village market $(\mathrm{km}), \mathrm{X}_{11}=$ distance to main market $(\mathrm{km}), X_{12}=$ transport cost(birr), $X_{13}=$ distance ferlizer source $(\mathrm{km}), X_{14}=$ distance improved seed source, $\mathrm{X}_{15}=$ distance chemical source, $\mathrm{X}_{17}=$ access to credit, $\varepsilon \mathrm{i}=$ error term.

\section{RESUlT AND DISCUSSION}

\subsection{Commercialization of Small holder farmers}

\subsubsection{Household and Crop Specific Level of Commercialization}

The degree of household commercialization in the study area ranged from 0 to 1 across the sampled households. As shown in Table 1, about $75 \%$ of households found to be at higher level of commercialization, selling on average $67 \%$ of the total quantity of the produce, whereas $17 \%$ and $7 \%$ of the households are at medium and low commercialization level, with average sell of $41 \%$ and $17 \%$ of the produce, respectively. In general the level of household commercialization in the study area was found to be $60 \%$, which is significantly above the national commercialization average, $35 \%$ (EEA, 2006; Gebre-ab (2006).

\begin{tabular}{|l|l|l|l|l|l|}
\hline Table 1: Household Level commercialization Index & Freq. & Percent & HCI & \multicolumn{3}{l|}{} \\
\hline Level of Commercialization & & & Mean & Max & Min \\
\hline & 40 & 6.98 & 0.17 & 0.30 & 0 \\
\hline Low $(0-0.3)$ & 101 & 17.63 & 0.43 & 0.5 & 0.31 \\
\hline Medium $(0.31-0.5)$ & 432 & 75.39 & 0.67 & 1 & 0.50 \\
\hline High $(0.51-1)$ & 573 & 100 & 0.59 & 1 & 0.0 \\
\hline Total & & &
\end{tabular}

Source: Own calculation

Besides understanding the degree of commercialization at household level, estimating commercialization index for each specific crop is very important since the tendency of household to sell could vary according to the type of major crop produced. For example supply decision of farmers who produce cash crop and those who produce food crops which can be sold or consumed on the farm could not be similar. Moreover, the argument on which commodities to target in the process of smallholder commercialization is also derived from the crop marketability index, agro-ecological condition and technical know-how of smallholders (Jaleta,etal.2009). As shown in table 2, the average commercialization index of coffee, ginger, turmeric, maize and sorghum were $80,83,85,51$ and $35 \%$ of the total production, respectively. This result may indicate that almost all of the crops produced in the study area could potentially contribute to household commercialization.

\begin{tabular}{|c|c|c|c|c|c|}
\hline \multirow[t]{2}{*}{ Type of crops } & \multirow[t]{2}{*}{ Obs } & \multicolumn{4}{|c|}{ Commercialization index } \\
\hline & & Mean & Min & Max & St.Dev \\
\hline Coffee & 140 & 0.8 & 0.5 & 1 & 0.18 \\
\hline Ginger & 49 & 0.83 & 0.6 & 1 & 0.15 \\
\hline Turmeric & 88 & 0.85 & 0.56 & 1 & 0.17 \\
\hline Maize & 151 & 0.51 & 0 & 0.96 & 0.27 \\
\hline Sorghum & 122 & 0.35 & 0 & 0.67 & 0.3 \\
\hline
\end{tabular}

Source: Own calculation

\subsubsection{Household Socioeconomic Characteristics}

Descriptive statistics of explanatory variables used in the regression model is presented in Table 3.

About $92 \%$ of the sampled households are male headed. This may positively enhance the process of commercialization in the study area, as male headed households believed to have a higher chance to participate in market than women headed due to higher social network (Gebreselassie \& Ludi, 2008). About $84 \%$ of the households are married. 
Regarding educational status, the average schooling of household is grade three. The result also indicates that on average sampled households in the study area have 23 years of farming experience. The average family size of sampled household is 6 . Large family size may ensure adequate supply of family labor for crop production. Large family could also absorb a significant portion of the produce to home consumption. The mean landholding of household is about $2.5 \mathrm{ha}$, which is by far above the national average, 1.06 ha (Salami et al, 2010). Larger landholding could be seen as an incentive to produce surplus for market. The average annual crop harvest of the household is 36.8 ql. High quantity of harvest could lead households to higher level of commercialization. The amount of output available in the stock during the beginning of new harvest and the marketed proportion of high value crops could critically affect the overall household commercialization. Household in the study area has on average $7.7 \mathrm{ql}$ of crop output in the stock at the beginning of new harvest. The result also showed that $76 \%$ of the total harvest of high value crops is marketed.

Distance imposes transaction cost to households and determines the volume of output sold. For example, households on average $2.17 \mathrm{~km}$ and $11.92 \mathrm{~km}$ away from village and main market center respectively. The average transport cost from the residence to village market is Birr 5.76. The average distance of source of fertilizer, improved seed and chemicals in the study area is 1.89, 0.94 and 5.89 $\mathrm{km}$ respectively. The credit services reached out only for $11 \%$ of farm households. The majority of households do not have access to credit.

\begin{tabular}{|l|l|l|l|l|l|}
\hline Table 3: Descriptive statistics of household socioeconomic characteristics \\
\hline Explanatory Variable & Obs & Mean & Std. Dev. & Min & Max \\
\hline Sex of HH & 153 & 0.92 & 0.28 & 0 & 1 \\
\hline Marital Status & 153 & 0.84 & 0.37 & 0 & 1 \\
\hline HH educational status & 153 & 3.2 & 3.44 & 0 & 12 \\
\hline Farming experience & 153 & 23.1 & 10.25 & 2 & 60 \\
\hline Family size & 153 & 5.9 & 1.92 & 1 & 10 \\
\hline Total land holding (hr) & 153 & 2.5 & 1.73 & 0.25 & 8 \\
\hline Total_harvest (ql) & 153 & 36.8 & 23.6 & 7 & 90 \\
\hline Stock at harvest (ql) & 153 & 7.7 & 4.6 & 0 & 30 \\
\hline Marketable portion of high value crops & 153 & 0.76 & 0.21 & 0 & 0.95 \\
\hline Dis. to nearst village market $(\mathrm{km})$ & 153 & 2.17 & 1.54 & 0.2 & 7 \\
\hline Transaction cost (Birr) & 153 & 5.76 & 2.41 & 0 & 15 \\
\hline Dis. to nearst main market $(\mathrm{km})$ & 153 & 11.92 & 1.18 & 1.5 & 27 \\
\hline Dis.to nearst source of ferlzer $(\mathrm{km})$ & 153 & 1.89 & 1.46 & 0 & 6 \\
\hline Dis.to nearst source of impvd.seed $(\mathrm{km})$ & 153 & 0.94 & 2.46 & 0 & 24 \\
\hline Dis.to nearst source of chemical $(\mathrm{km})$ & 153 & 5.89 & 8.96 & 0 & 27 \\
\hline Access to credit & 153 & 0.11 & 0.32 & 0 & 1 \\
\hline
\end{tabular}

\subsubsection{Determinants of Commercialization of Smallholder Farmers}

The result of the linear regression model is presented in table 6 . The three possible functional forms, Linear-linear, Log-log and Log-linear or Semi-log, are compared using MLE approach to choose the best fitted model. The Box-Cox test shown in Appendix 1, in appendix section, indicated that the best fitting transformation is $\theta=.74$, which is a bit closer to $\theta=1$; accordingly we select linear - linear functional form. Again $\mathrm{R}^{2}$ was used to compare linear - linear vs linear - $\log$ model since the two functional forms have similar LHS variables. As indicated in Appendix 2, in appendix section, linear-linear functional form was chosen as the lead equation, since it has the highest value of $\mathrm{R}^{2}$ of 0.5321. Variance Inflation Factor was also computed to test multi collinearity problem. The VIF results shown in Appendix 3 indicate that there is no serious multi collinearity problem

Households' socio economic condition could significantly affect the extent of household commercialization. Table 4 summarized household level determinants of crop commercialization. As shown in the Table, the extent of commercialization is positively determined by household education level. This is probably because education could improve the level of household understanding about market dynamics and therefore help them to make timely decision about the amount of output sold (Makhura et al, 2001; John \& Dawit, 2007). Similar with Enete et al (2009), farming experience positively affects the degree of commercialization. Because experienced farmers could have more trading partners' and this helps them to discover market information at lower cost. 
Family size is negatively influence the level of household commercialization. As indicated in the table, the extent of output sale decreases by 1.1 quintal for each additional individual in the family members. This relationship is expected, since larger family size could potentially absorb a significant portion of the produce to home consumption (Gebreslassie et al, 2015). On contrary to Olwande et al. (2010) and Edward and John (2012) land holding was found to be negatively associated with the extent of commercialization. The level of crop commercialization decreases by 2.7 quintal for every additional hectare of land added to the household holding. This result may revealed that the extent of commercialization be more influenced by land allocation decision than total land holding.

Consistent with previous studies (Gebreselassie \& Sharp, 2008; Oteh \& Nwachukwu, 2014), volume of total harvest was positively affect the level of household commercialization. As shown in the table, the level of commercialization was increased by 0.32 quintal for each additional quintal of harvest, keeping all other variables constant. This may suggest that building the capacity of households to produce surplus production could be critical to improve households' commercialization level in the Ethiopian context. We also found that the marketable proportion of high value crops significantly contributed to household's commercialization level. The result showed that the extent of commercialization was increased by 55 percent if we increase the marketable proportion of high value crops by 1 percent.

Access to market information was found to be an important factor in commercialization process. For example, distance from household residence to the nearest village market significantly reduces the level of commercialization. The extent of household commercialization decreases by 0.74 quintal for each additional kilometer in the distance from household's residence to the nearest village market. This implies that access to information both on input and out market could help farmers to make production decision on the basis of market signal and allows them to produce mostly for market. Similarly with the findings of Gebremedhin and Jaleta (2010) we also found that the extent of commercialization was higher for households who have access to improved agricultural technology. For instance, distance to the nearest source of fertilizer and improved seed significantly reduce the level of commercialization. This result may shows that access to modern agricultural technology helps farmers to produce surplus to satisfy both consumption and market demand.

\begin{tabular}{|c|c|c|}
\hline Variables & Coef. & Robust Sd.Er \\
\hline Constant & 21.42 & 5.67 \\
\hline Sex of HH & -3.95 & 4.15 \\
\hline Marital Status & -4.34 & 3.33 \\
\hline HH educational status & $0.59 *$ & 0.36 \\
\hline Farming experience & $0.32 * * *$ & 0.12 \\
\hline Family size & $-1.12^{*}$ & 0.64 \\
\hline Total land holding (hr) & $-2.67 * *$ & 1.28 \\
\hline Total harvest (ql) & $0.32 * * *$ & 0.10 \\
\hline Stock at harvest (ql) & -0.12 & 0.23 \\
\hline Marketability index of high value crops & $53.3 * * *$ & 5.78 \\
\hline Dis. to nearst village market $(\mathrm{km})$ & $-0.74 *$ & 0.95 \\
\hline Dis. to nearst main market $(\mathrm{km})$ & -0.11 & 0.55 \\
\hline Transportation cost (Birr) & 0.04 & 0.20 \\
\hline Dis.to nearst source of ferlzer $(\mathrm{km})$ & $-1.47 *$ & 1.02 \\
\hline Dis.to nearst source of impvd.seed $(\mathrm{km})$ & $0.52 *$ & 0.36 \\
\hline Dis.to nearst source of chemical $(\mathrm{km})$ & -0.10 & 0.13 \\
\hline Access to credit & -1.05 & 4.35 \\
\hline Number of Obs & & 153 \\
\hline $\mathrm{F}(16, \quad 136)=$ & & 11.8 \\
\hline Prob $>\quad F$ & & 0.0000 \\
\hline R-squared & & 0.5321 \\
\hline Root MSE & & 13.22 \\
\hline
\end{tabular}

Std.Err is standard error

*Denotes Significance Level at $10 \%$

**Denotes Significance Level at 5\%

***Denotes Significance Level at $1 \%$

Source: Own estimate (result) 
Smallholder Commercialization and Commercial Farming in Coffee-Spice Based Farming System of South West Ethiopia.

\subsection{Large Scale Commercial Farms}

\subsubsection{Type and Distribution of Commercial Farm}

Decision on which commodities to target in large scale commercial farming is basically depend on the expected cost and profitability of the commodity, which in turn mainly determined by the suitability of agro-ecology, technical know-how and availability of basic services like power, communication, water, transportation, labor and other required services. Table 5 summarized the status of commercial farms in terms of crop type. The result showed that the type of crop cultivated in commercial farms are almost similar in Sheka and Kaffa zones, whereas slightly diverse in the case of Bench Maji zone. While commercial farms in Bench Maji zone grow 14 (fourteen) type of crops, only 6 (six) crops are cultivated in commercial farming in Sheka and Kaffa Zones.

Due to the agro-ecology comparative advantage, the majority of commercial farms in the study area involved in growing of high value crops, such as coffee, spices (ginger, turmeric, black pepper and cardamom) and tea as compared to other crops. As indicated in the table, $93.9 \%, 92.2 \%$ and $50 \%$ of commercial farms in Sheka, Kaffa and Bench Maji Zones respectively, engaged in growing of high value crops. However, among the high value crops, coffee is the dominant one widely grown by commercial farms in the study area constituting about $81 \%, 89 \%$ and $41 \%$ in Sheka, Kaffa and Bench Maji zones, respectively.

Table 5. Type of crops grown in Commercial farms

\begin{tabular}{|c|c|c|c|c|c|c|}
\hline \multirow[t]{3}{*}{ Type of crop produce } & \multicolumn{6}{|c|}{ Zone } \\
\hline & \multicolumn{2}{|c|}{ Sheka } & \multicolumn{2}{|c|}{ Kaffa } & \multicolumn{2}{|c|}{ Bench Maji } \\
\hline & Freq & Percent & Freq & Percent & Freq & Percent \\
\hline Maize & 0 & 0 & 3 & 4.7 & 10 & 16.6 \\
\hline Sorghum & 1 & 3.03 & 1 & 1.56 & 4 & 6.7 \\
\hline Rice & 0 & 0 & 0 & 0 & 5 & 8.3 \\
\hline Haricot Bean & 0 & 0 & 0 & 0 & 1 & 1.7 \\
\hline Ginger & 1 & 3.03 & 0 & 0 & 2 & 3.3 \\
\hline Turmeric & 2 & 6.06 & 0 & 0 & 1 & 1.7 \\
\hline Black pepper & 0 & 0 & 0 & 0 & 1 & 1.7 \\
\hline Cardamom & 0 & 0 & 1 & 1.56 & 0 & 0 \\
\hline Coffee & 27 & 81.82 & 57 & 89.06 & 25 & 41.6 \\
\hline Tea & 1 & 3.03 & 1 & 1.56 & 0 & 0 \\
\hline Sesame & 0 & 0 & 0 & 0 & 3 & 5 \\
\hline Cotton & 0 & 0 & 0 & 0 & 1 & 1.7 \\
\hline Banana & 1 & 3.03 & 1 & 1.56 & 0 & 0 \\
\hline Mango & 0 & 0 & 0 & 0 & 1 & 1.7 \\
\hline Other Fruits & 0 & 0 & 0 & 0 & 3 & 5 \\
\hline Other Spices & 0 & 0 & 0 & 0 & 1 & 1.7 \\
\hline Other Pulse & 0 & 0 & 0 & 0 & 2 & 3.3 \\
\hline Total & 33 & 100 & 64 & 100 & 60 & 100 \\
\hline
\end{tabular}

Source: Own calculation

In addition to high value crops, cereals, fruits, pulse and other industrial crops are also grown in the surveyed commercial farms with notable variation in the extent of area coverage across the study area. Table 6 summarized total land area and percentage distribution of crop grown in commercial farms. According to the result, sorghum is the only cereal crop grown in commercial farms covering 14.6 hectare $(0.2 \%)$ of crop land in Sheka zone, whereas maize and sorghum covered 1050.2 hectare $(10.4 \%)$ and 125.9 hectare $(1.3 \%)$ of crop land in Kaffa zone, respectively.

Moreover, maize, sorghum and rice respectively covered 413.5 hectare $(2.5 \%), 150$ hectare $(0.9 \%)$ and 1149.3 hectare $(6.9 \%)$ of crop land of commercial farms in Bench Maji Zone. High value crops, such as coffee, ginger, turmeric, black pepper, cardamom and tea, covered a total land area of $\mathbf{8 4 1 3 . 2}$ hectares $\mathbf{( 9 9 . 8 \% )}$ ) in Sheka zone, 8773.2 hectares (87.2\%) in Kaffa zone and 13857.3 hectares $\mathbf{8 3 . 5 \%}$ ) in Bench Maji zone. However, the extent of land area covered with each specific high value crop in commercial farms show variation from one zone to another. For example, coffee alone covered $63.2 \%, 63.7 \%$ and $76 \%$ of the total crop land area of commercial farms in Sheka, Kaffa and 
Bench Maji zones, respectively. While tea covered $36.2 \%$ and $23.4 \%$ of total land area of commercial farms in Sheka and Kaffa zones respectively, $8.2 \%$ of the total land area of commercial farms in Bench Maji zone covered with spices crop. This result may indicate that coffee still remained relatively more attractive for the majority of large scale commercial farms as compared to other alternative high value crops.

\begin{tabular}{|c|c|c|c|c|c|c|}
\hline \multirow[t]{3}{*}{ Type of crop } & \multicolumn{6}{|l|}{ Zone } \\
\hline & \multicolumn{2}{|l|}{ Sheka } & \multicolumn{2}{|l|}{ Kaffa } & \multicolumn{2}{|l|}{ Bench Maji } \\
\hline & $\begin{array}{l}\text { Total land area } \\
\text { (hr) }\end{array}$ & $\begin{array}{l}\text { Percent } \\
\text { share }(\%)\end{array}$ & $\begin{array}{l}\text { Total land } \\
\text { area }(\mathrm{hr})\end{array}$ & $\begin{array}{l}\text { Percent } \\
\text { share }(\%)\end{array}$ & $\begin{array}{ll}\text { Total land } \\
\text { area }(\mathrm{hr})\end{array}$ & $\begin{array}{l}\text { Percent } \\
\text { share }(\%)\end{array}$ \\
\hline Maize & 0 & 0 & 1050.2 & 10.4 & 413.5 & 2.5 \\
\hline Sorghum & 14.6 & 0.2 & 125.9 & 1.3 & 150.4 & 0.9 \\
\hline Rice & 0 & 0 & 0 & 0 & 1149.3 & 6.9 \\
\hline Haricot Bean & 0 & 0 & 0 & 0 & 24.9 & 0.2 \\
\hline Ginger & 12.7 & 0.2 & 0 & 0 & 985.7 & 5.9 \\
\hline Turmeric & 27.6 & 0.3 & 0 & 0 & 30 & 0.2 \\
\hline Black pepper & 0 & 0 & 0 & 0 & 235 & 1.4 \\
\hline Cardamom & 0 & 0 & 11.5 & 0.1 & 0 & 0 \\
\hline Coffee & 5322.9 & 63.2 & 6411.7 & 63.7 & 12606.6 & 76.0 \\
\hline Tea & 3050 & 36.2 & 2350 & 23.4 & 0 & 0 \\
\hline Sesame & 0 & 0 & 0 & 0 & 179.5 & 1.1 \\
\hline Cotton & 0 & 0 & 0 & 0 & 13.4 & 0.1 \\
\hline Banana & 0 & 0 & 111 & 1.1 & 0 & 0 \\
\hline Mango & 0 & 0 & 0 & 0 & 25 & 0.2 \\
\hline Other Fruits & 0 & 0 & 0 & 0 & 97.1 & 0.6 \\
\hline Other Spices & 0 & 0 & 0 & 0 & 110 & 0.7 \\
\hline Other Pulse & 0 & 0 & 0 & 0 & 567 & 3.4 \\
\hline Total & 8427.8 & 100 & 10060.3 & 100 & 16587.4 & 100 \\
\hline
\end{tabular}

Source: Own calculation

The study area, Sheka, Kafa and Bench Maji zones, is one of the major producers of high value crops in SNNPRs. This has been best reflected in it's contribution to the region total crop land area of high value crops. Table 7 presented the percentage distribution of total land area of commercial farms in SNNPRS by crop category.

Coffee, spices and tea crops were grown in SNNPRS on an estimated total land area of $\mathbf{2 4 4 8 6 . 5}$ hectare, 1434.9 hectare and 5400 hectare, respectively at commercial farm level. As shown in the table, the three zones together contributed $99.4 \%, 98.4 \%$ and $100 \%$ to the total land area of coffee, spices and tea farms, respectively. Given that these crops are one of the few crops the country's export is highly depend on, commercial farms in the study area could significantly contribute to foreign currency earnings if emphasis is given on quality and post harvest management, the necessary physical and institutional infrastructures development, and all actors along the value chain integrate efficiently.

Table 7. Percentage distribution of total crop land by major crop category.

\begin{tabular}{|l|l|l|l|l|l|l|}
\hline Type of crop & $\begin{array}{l}\text { SNNPRs Total crop } \\
\text { land area (hr) }\end{array}$ & \multicolumn{2}{l}{$\begin{array}{l}\text { Share of Sheka, Kaffa \& Bench } \\
\text { Maji Zones }\end{array}$} & & \\
\hline & & $\begin{array}{l}\text { Total Crop land } \\
\text { area (hr) }\end{array}$ & $\begin{array}{l}\text { Percent } \\
\text { share (\%) }\end{array}$ & & & \\
\hline & & 1463.7 & 12.1 & & & \\
\hline Maize & 12082.41 & 290.9 & 89.8 & & \\
\hline Sorghum & 323.9 & 1149.3 & 100 & & \\
\hline Rice & 1149.3 & 24.9 & 2.6 & & \\
\hline Haricot Bean & 961.6 & 998.4 & 97.8 & & \\
\hline Ginger & 1020.8 & 57.6 & 100 & & \\
\hline Turmeric & 57.6 & 235 & 100 & & \\
\hline Black pepper & 235 & 11.5 & 100 & & \\
\hline Cardamom & 11.5 & 24341.2 & 99.4 & & \\
\hline Coffee & 24486.5 & 5400 & 100 & & \\
\hline Tea & 5400 & 179.5 & 67.6 & & \\
\hline Sesame & 265.5 & & & & \\
\hline
\end{tabular}


Smallholder Commercialization and Commercial Farming in Coffee-Spice Based Farming System of South West Ethiopia.

\begin{tabular}{|l|l|l|l|l|l|}
\hline Cotton & 21396.5 & 13.4 & 0.1 & & \\
\hline Banana & 672 & 111 & 16.5 & & \\
\hline Mango & 25 & 25 & 100 & & \\
\hline Other Fruits & 97.1 & 97.1 & 100 & & \\
\hline Other Spices & 110 & 110 & 100 & & \\
\hline Other Pulse & 1217 & 567 & 46.6 & & \\
\hline Total & 69511.71 & 35075.5 & 50.5 & & \\
\hline
\end{tabular}

Source: Own calculation

\subsubsection{Cropping System and Use of Improved Agricultural Technologies}

Large scale commercial farm is supposed to follow specialized way of production system and use capital intensive and market oriented farming system to envisage the expected benefit. Table 8 summarized cropping system of commercial farms in the study area. The result showed that about 90\% and 93\% of commercial farms in Sheka and Kaffa zones respectively follow sole cropping system, whereas only $60 \%$ of commercial farms follow the same system in Bench Maji zone. Unexpectedly, about $14 \%$ of the commercial farms in Bench Maji zone follow mixed cropping system growing three to five crops in a single farm. The findings here may suggest that commercial farms in the study area should give more focus on sole cropping system to exploit the benefit of specialization.

\begin{tabular}{|c|c|c|c|c|c|c|}
\hline \multirow[t]{3}{*}{ Cropping System } & \multicolumn{6}{|l|}{ Zone } \\
\hline & \multicolumn{2}{|c|}{ Sheka } & \multicolumn{2}{|c|}{ Kaffa } & \multicolumn{2}{|c|}{ Bench Maji } \\
\hline & Freq & Percent & Freq & Percent & Freq & Percent \\
\hline Sole Crop farm & 26 & 89.7 & 56 & 93.3 & 21 & 60 \\
\hline Mixed Crop (2 crops) farm & 2 & 6.9 & 4 & 6.7 & 9 & 25.7 \\
\hline Mixed Crop (3 crops) farm & 1 & 3.4 & 0 & 0 & 1 & 2.9 \\
\hline Mixed Crop (4 crops) farm & 0 & 0 & 0 & 0 & 2 & 5.7 \\
\hline Mixed Crop (5 crops) farm & 0 & 0 & 0 & 0 & 2 & 5.7 \\
\hline Total & 29 & 100 & 60 & 100 & 35 & 100 \\
\hline
\end{tabular}

Source: Own calculation

Improved seed, Dap, Urea, pesticides, fungicide and herbicides are some of the most important agricultural technologies that are commonly used in agriculture to increase productivity at plot level. In fact herbicides and pesticides, with integration of other management technique, are commonly used for the control of weed and pest; thus the total area of crop land treated with chemicals, such as herbicides, pesticides and fungicides, may not adequately indicate the status of commercial farm in terms of modern input use.

The Important inputs here among others are greater and efficient use of fertilizer and improved seeds, along modern farm management practices. Graph 2 presented the level of modern inputs use by crop category. As shown in the graph, modern inputs did not used in all crops grown in commercial farms. There is also discrepancy between the size of land area applied with improved inputs and the total crop land of each specific crop. For example, the total Urea and Dap applied in coffee farm was found to be 6931 hectare and 6956 hectare, respectively, which is about $28 \%$ of the total crop land of coffee. The total land area treated with herbicides in coffee farm was found to be 8146.8 hectare, which is $33.3 \%$ of the total crop land area of coffee.

Maize is the other crop relatively treated with more inputs. The total area of maize farm in which Urea and Dap applied was estimated to be 1152 hectare and 1155 hectare, respectively, which is about 79 $\%$ of the total land area covered with maize. Again total land area of maize farm covered with improved maize seed was estimated to be 458 hectare, which covered only $31 \%$ of the total land area of maize. Regarding chemical use, $100 \%$ of the total land area of maize (1482 hectare) was treated with herbicide. This is probably because weed control through slashing could be costly as compared to chemicals since the frequency of weed growth is high in the study area due to high moisture and temperature availability (Kifelew, etal. 2015). In general result presented in Graph 2 may indicate that commercial farms in the study area operate their farming activity below the expected level in terms of modern input use. 


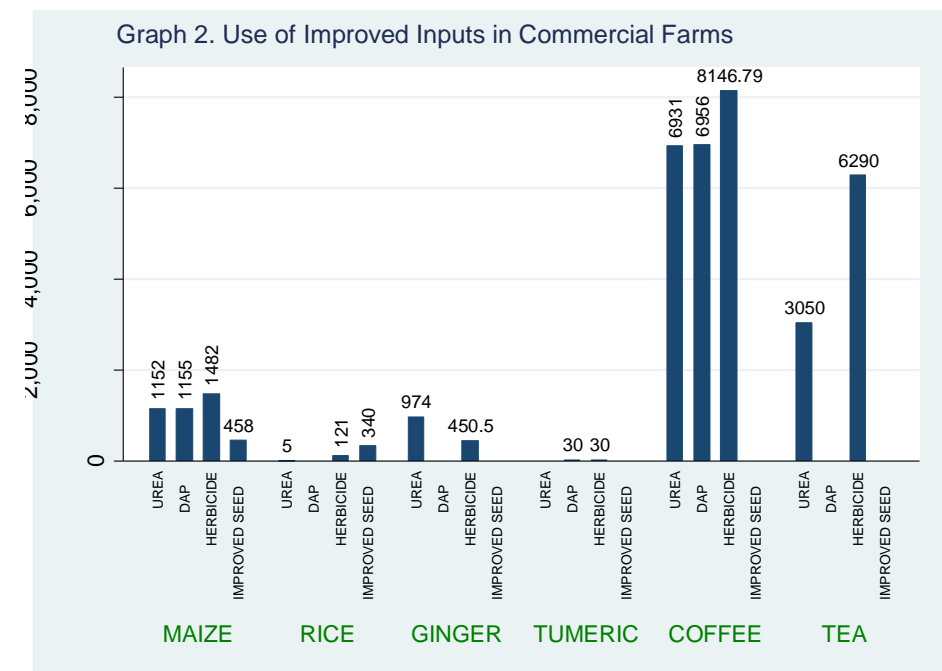

\section{CONCLUSION AND RECOMMENDATION}

The level of smallholder commercialization in the study area was relatively higher. The result showed that about $75 \%$ of sampled households in the study area found to be at higher level of commercialization, selling on average about $66.7 \%$ of the annual crop produce. However, the overall average household commercialization index of the study area was found to be $60 \%$, which is considerably above the national average commercialization level, 35\% (EEA, 2006; Gebre-ab (2006). Besides, the average marketability index of each specific crop in the study area was estimated. The result indicated that the average commercialization index of coffee, ginger, turmeric, maize and sorghum were $80,83,85,51$ and $35 \%$ of the total production, respectively. This result may indicate that almost all of the major crops produced in the study area could contribute to household commercialization. However, since these crops are usually produced for export market, smallholder farmers need to be aware of about the issue of quality, sanitary and phytosanitary standards (Henson et al. 1999).

The extent of household commercialization is significantly influenced by the observed socio economic characteristics, access to market information and improved agricultural technology. According to the result, household educational level and farming experience, total harvest and the marketable proportion of high value crops positively affect the extent of household commercialization, whereas family size, land holding, distance to the nearest village market, source of fertilizer and improved seed negatively affect the degree of household commercialization. Important policy implication here is that improving market infrastructure for high value crops and strengthening agricultural technology delivering system could enhance the commercial transformation of small holder agriculture in the study area.

The majority of commercial farms in the study area involved in production of high value crops such as coffee, spices (ginger, turmeric, black pepper and cardamom) and tea. Given that these crops are one of the major crops being grown by smallholder farmers, large scale commercial farms could significantly enhance the process of smallholder farmers' commercialization in the study area, if commercial farms could use smallholder farmers as out-grower to ensure timely and regular supply. Regarding cropping system, the result showed that about $90 \%, 93 \%$ and $60 \%$ of commercial farms in Sheka, Kaffa and Bench Maji zones respectively follow sole cropping system. The findings here may suggest that commercial farms in the study area should give more focus on sole cropping system to exploit the benefit of specialization. Commercial farms in the study area did not use improved crop technologies in all crops being grown. There is also discrepancy between the size of land area applied with improved inputs and the total crop land of each specific crop. According to the result only about $28 \%$ of the total crop land of coffee is treated with Urea and Dap. However, maize is the only crop relatively treated with more inputs. The total area of maize farm in which Urea and Dap applied was estimated to be 1152 hectare and 1155 hectare, respectively, which is about $79 \%$ of the total land area covered with maize. Again total land area of maize farm covered with improved maize seed was estimated to be 458 hectare, which covered only $31 \%$ of the total land area of maize. In general commercial farms in the study area operate their farming activity below expected level in terms of modern input use. 
Smallholder Commercialization and Commercial Farming in Coffee-Spice Based Farming System of South West Ethiopia.

\section{Appendix}

Appendix.1. Box-Cox test

\begin{tabular}{|l|l|l|l|l|l|}
\hline & & & & Log likelihood $=$ & -1017.2 \\
\hline & & & & Number of obs = & 150 \\
\hline & & & & LR chi2(16) = & 76.46 \\
\hline & & & & Prob > chi2 = & 0 \\
\hline HCI5_1 & Coef. & Std. Err. & z & P>z [95\% Conf. & Interval] \\
\hline /theta & 0.7475 & 0.1152983 & 6.48 & $0.000 \quad .5215091$ & 0.97347 \\
\hline
\end{tabular}

\begin{tabular}{|c|c|c|c|c|c|}
\hline /theta & 0.7475 & 0.1152983 & 6.48 & .5215091 & 0.97347 \\
\hline Estimates of & Scale variant & parameters & & & \\
\hline
\end{tabular}

\begin{tabular}{|l|l|l|}
\hline & Coef. & \\
\hline Notrans & & \\
\hline Constant & 58.602 & \\
\hline Sex. HH & -21.133 & \\
\hline
\end{tabular}

Mart.Staus HH

Educ HH

Farm exp

Family_Size

Land holding

Total_harvst

Mak.porn.HVC

Stock at Hrvst

$-12.708$

Dis_vill.mkt_km

Tran.cos.vil.mkt

diskm.main.mkt

diskm.sor.fertzr

diskm.sor..seed

2.109

1.067

$-3.617$

diskm.sor.chmkl

Acc.credit

$-9.792$

/sigma

1.136

158.916

$-0.664$

$-2.010$

0.150

0.344

$-5.716$

1.924

$-0.357$

$-5.526$

43.325

\begin{tabular}{|l|l|l|l|}
\hline Test & Restricted & LR statistic & P-value \\
\hline H0: & log likelihood & chi2 & Prob > chi2 \\
\hline theta $=-1$ & -1611.1119 & 1187.9 & 0 \\
\hline theta $=0$ & -1066.0021 & 97.68 & 0 \\
\hline theta $=1$ & -1019.2642 & 4.21 & 0.04 \\
\hline
\end{tabular}

Source: Own estimation

Appendix.2. $\mathrm{R}^{2}$ Comparison for choice of linear - linear vs linear - log

\begin{tabular}{|c|c|c|c|c|}
\hline & \multicolumn{4}{|c|}{ Model Type } \\
\hline Variables & \multicolumn{2}{|c|}{ Linear - Linear } & \multicolumn{2}{|l|}{ Lin - Log } \\
\hline & & Robust & & Robust \\
\hline & Coef. & Std. Err. & Coef. & Std. Err. \\
\hline Constant & 21.42 & 5.67 & 20.98 & 17.38 \\
\hline Sex of HH & -3.95 & 4.15 & -4.89 & 5.05 \\
\hline Marital Status & -4.34 & 3.33 & -3.92 & 3.35 \\
\hline HH Educt.level & $0.59 *$ & 0.36 & 0.35 & 0.23 \\
\hline Farming expr. & $0.32 * * *$ & 0.12 & $6.84 * * *$ & 2.59 \\
\hline Family Size & $-1.12 *$ & 0.64 & -5.85 & 4.06 \\
\hline Total land holdng (hr) & $-2.67 * *$ & 1.28 & $-9.50 * * * *$ & 2.81 \\
\hline Total harvest (ql) & $0.32 * * *$ & 0.10 & $13.48 * * *$ & 3.14 \\
\hline Stock at new harvest (ql) & -0.12 & 0.23 & -0.80 & 0.74 \\
\hline Marketable portion of HVC & $53.3 * * *$ & 5.78 & $5.95 * * *$ & 0.62 \\
\hline Dis.nearst Vill Markt (km) & $-0.74 *$ & 0.95 & $-3.87 * *$ & 1.77 \\
\hline
\end{tabular}


Abdu Mohammed et al.

\begin{tabular}{|l|l|l|l|l|}
\hline \hline Transport cost vill. Markt (Birr) & -0.11 & 0.55 & $-1.34^{* *}$ & 0.55 \\
\hline Dis.nearst Main Markt (km) & 0.04 & 0.20 & 1.55 & 2.79 \\
\hline Dis.nrst.sourc of fertlzr (km) & $-1.47^{*}$ & 1.02 & -0.17 & 0.44 \\
\hline Dis.nrst.sourc.imprvd seed (km) & $-0.52^{*}$ & 0.36 & -0.07 & 0.40 \\
\hline Dis.nrst.sourc. chemical (km) & -0.10 & 0.13 & -0.12 & 0.22 \\
\hline Acess to credit & -1.05 & 4.35 & -3.36 & 4.20 \\
\hline Number of Obs = & & 153 & & 153 \\
\hline F( 16, 136) = & & 11.8 & & 20.36 \\
\hline Prob > F & & 0.0000 & & 0.0000 \\
\hline R-squared $=$ & & 0.5321 & & 0.521 \\
\hline Root MSE $=$ & & 13.222 & & 13.38 \\
\hline
\end{tabular}

Source: Own estimation

\begin{tabular}{|l|l|l|}
\hline \multicolumn{2}{|l|}{} \\
Appendix. 3. Multicollinearity Test & \multicolumn{2}{l|}{ Linear-linear } \\
\hline Variables & VIF & $1 /$ VIF \\
\hline & 3.59 & 0.28 \\
\hline Total land holdng (hr) & 3.45 & 0.29 \\
\hline Total harvest (ql) & 1.9 & 0.53 \\
\hline Dis.nearst Main Markt (km) & 1.73 & 0.58 \\
\hline Dis.nearst Vill Markt (km) & 1.71 & 0.58 \\
\hline Farming expr. & 1.7 & 0.59 \\
\hline Dis.nrst.sourc of fertlzr (km) & 1.7 & 0.59 \\
\hline Dis.nrst.sourc. chemical (km) & 1.69 & 0.59 \\
\hline Dis.nrst.sourc.imprvd seed (km) & 1.44 & 0.70 \\
\hline Family Size & 1.41 & 0.71 \\
\hline Tranport cost vill. Markt (Birr) & 1.34 & 0.75 \\
\hline Stock at new harvest (ql) & 1.33 & 0.75 \\
\hline HH Educt.level & 1.31 & 0.76 \\
\hline Sex of HH & 1.23 & 0.81 \\
\hline Marital Status & 1.21 & 0.83 \\
\hline Markatable portion of HVC & 1.19 & 0.84 \\
\hline Acess to credit & 1.75 & \\
\hline Mean VIF & & \\
\hline
\end{tabular}

Source: Own estimation

\section{REFERENCES}

[1] Baumgartner, Philipp Braun, Joachim Von Abebaw, Degnet and Müller, M. (2013). I MPACTS OF LARGE - SCALE LAND INVESTMENTS ON INCOME, PRICES , AND EMPLOYMENT : EMPIRICAL ANALYSES IN ETHIOPIA. In Annual World Bank Conference on Land and Poverty (pp. 1-35). Washington DC, USA

[2] Bonaglia Federico, Patrizia Labella and Jane Marshal. 2007. Promoting Commercial Agriculture in Africa. ATDF Journal Volume 5, Issue 1/2. OECD Development Centre, Paris, France

[3] CSA. (2015). Report on Area and Production of Major Crops. Central Statistical Agency, Agricultural Sample Survey, Adiss Ababa, Ethiopia

[4] CSA. (2013). Population Projection of Ethiopia for All Regions At Wereda Level from 2014 2017. Adiss Ababa, Ethiopia.

[5] CSA. (2011). Large and Medium Scale Commercial Farms Sample Survey. Adiss Ababa.

[6] COX, D. R. (1962), "Further results on tests of separate families of hypotheses ", Journal of the Royal Statistical Society Series B, 24, 406-424.

[7] Edward Martey, R. M. A.-H. and J. K. M. K. (2012). Commercialization of smallholder agriculture in Ghana: A Tobit regression analysis. African Journal of Agricultural Research, 7(14), 2131-2141. http://doi.org/10.5897/AJAR11.1743

[8] EEA (2006). Evaluation of the Ethiopian agricultural extension with particular emphasis on the Participatory Demonstration and Training Extension System. Research Report, Ethiopian Economic Association, Addis Ababa, Ethiopia. 
[9] Enete AA, Igbokwe EM (2009). Cassava Market Participation Decision of Household in Africa. Tropicultura, 27(3): 129-136.

[10] Gebre-ab N (2006). Commercialization of small holder agriculture in Ethiopia. Note and Papers Series,3.

[11] Gebremedhin, B. and, \& Jaleta, M. (2012). Market Orientation and Market Participation of Smallholders in Ethiopia: Implications for Commercial Transformation. In Selected Paper presented at the International Association of Agricultural Economists (IAAE) Triennial Conference, Foz do lguacu, Brazil, 18-24 August, 2012.

[12] Gebremedhin, Berhanu and Jaleta, M. (2010). Commercialization of Smallholders: Is Market Participation Enough? In Paper presented at the Joint 3rd African Association of Agricultural Economists (AAAE) and 48th Agricultural Economists Association of South Africa (AEASA) Conference, Cape Town, South Africa, September 19-23, 2010. Cape Town.

[13] Gebreselassie, S., \& Ludi, E. (2008). Agricultural Commercialisation in Coff ee Growing Areas of Ethiopia 1, (March).

[14] Gebreselassie, S., \& Sharp, K. (2008). Commercialisation of Smallholder Agriculture in Selected Tef-growing Areas of Ethiopia, (March).

[15] Gebreslassie, K. M. and K. M. (2015). Crop commercialization and smallholder farmers' livelihood in Tigray region, Ethiopia. Journal of Development and Agricultural Economics, 7(9), 314-322. http://doi.org/10.5897/JDAE2015.0649

[16] Govereh J, Jayne TS, Nyoro J (1999). Smallholder commercialization, interlinked markets and food crop productivity: Cross-country evidence in eastern and southern Africa. http://www.aec.msu.edu/fs2/ag_transformation/atw_govereh.

[17] Greene WH (2003). Econometric Analysis, Fifth edition (Prentice Hall, Upper Saddle River, $\mathrm{NJ})$.

[18] Henson S, Loader R, Swinbank A and Bredahl M. 1999. The impacts of sanitary and phytosanitary measures on developing country exports of agricultural and food products. The World Bank and WTO. Geneva. (Draft document for discussion)

[19] Jaleta, M., Gebremedhin, B., \& Hoekstra, D. (2009). Smallholder commercialization : Processes , determinants and impact. Adiss Ababa, Ethiopia.

[20] James Keeley, Wondwosen Michago Seide, A. E. and A. L. K. (2014). Large-scale land deals in Ethiopia: Scale, trends, features and outcomes to date. London, United Kingdom: International Institute for Environment and Development.

[21] John, P. and, \& Dawit, A. (2007). Determinants of Smallholder Commercialization of Food Crops: Theory and Evidence From Ethiopia (IFPRI Discussion Paper 00745).

[22] Kifelew, H., Eshetu, T., \& Abera, H. (2015). Critical Time of Weed Competition and Evaluation of Weed Management Techniques on Ginger ( Zengeber Officinale ) at Tepi in South West Ethiopia. International Journal of Research Studies in Agricultural Sciences (IJRSAS), 1(3), 5-10.

[23] Kuma, T. (2003). Private Investment in Commercial Agriculture in Ethiopia : Opportunities and Constraints. Adiss Ababa, Ethiopia.

[24] Makhura M, Kirsten J, Delgado C (2001). Transaction Costs and Smallholder participation in the maize market in the Northern Province of South Africa. Seventh Eastern and Southern Africa regional Conference, February, pp. 463-467.

[25] MoA. (2011). Adapting to Climate Change through Participatory Promotion and Demonstration of Conservation Agriculture (CA) in East Gojam Zone, Amhara National Regional state".

[26] NBE. (2014). The Overall Economic Performance of Ethiopia. Adiss Ababa, Ethiopia.

[27] Olwande J, Mathenge M (2010). Market Participation among the Poor Rural Households in Kenya. Tegemeo Institute of Agricultural Policy and Development.

[28] Oteh, O. U., \& Nwachukwu, I. N. (2014). Efect of Commercialization on Productive Capacity Among Cassava Producing Households in Ikwuano Local Government Area of Abiata State , Nigeria, 14(3), 213-220. 
[29] Paul J. Strasberg, T. S. Jayne, Takashi Yamano, James Nyoro, D. K. and J. S. (1999). EFFECTS OF AGRICULTURAL COMMERCIALIZATION ON FOOD.

[30] PESARAN, M. H. (1974), "On the general problem of model selection", Review of Economic Studies 41, 153-171.

[31] Rahut, D.B., Castellanos, I.V., Sahoo, P., 2010, Commercialization of Agriculture in the Himalayas, Institute of Developing Economies, IDE Discussion paper no. 265.

[32] Salami, Adeleke; Kamara, Abdul B.; Brixiova, Zuzana (2010), Smallholder Agriculture in East Africa: Trends, Constraints and Opportunities, Working Papers Series $\mathrm{N}^{\circ} 105$ African Development Bank, Tunis, Tunisia.

[33] SNNPRS Investment Expansion Main Process Website. http://www.southinvest.gov.et/

[34] Tilman, A. (2000) Linkages and Spillovers between Transnational Corporations and Small and Medium-Sized Enterprises in Developing Countries - Opportunities and Policies. Reports and Working Papers 5/2000. German Development Institute, Berlin.

[35] Yassin, A. (2014). Transnational Large Scale Agricultural Firms in Gambella Regional State, Ethiopia : Local Potentials, Opportunities and Constraints for Market Linkage and Contractual Farming Schemes. 